\title{
A tough trade-off? The asymmetrical impact of populist radical right inclusion on satisfaction with democracy and government
}

\author{
Eelco Harteveld ${ }^{1, \star}\left(\mathbb{D}\right.$, Andrej Kokkonen ${ }^{2}$, Jonas Linde $^{3}$ and Stefan Dahlberg ${ }^{4}$ \\ ${ }^{1}$ Department of Political Science, University of Amsterdam, ${ }^{2}$ Department of Political Science, University of Gothenburg, \\ ${ }^{3}$ Department of Comparative Politics, University of Bergen and ${ }^{4}$ Department of Humanities and Social Sciences, Mid \\ Sweden University \\ ${ }^{\star}$ E-mail: e.harteveld@uva.nl
}

(Received 15 January 2020; revised 10 November 2020; accepted 11 November 2020)

\begin{abstract}
Populist radical right (PRR) parties are increasingly included in coalition governments across Western Europe. How does such inclusion affect satisfaction with democracy (SWD) in these societies? While some citizens will feel democracy has grown more responsive, others will abhor the inclusion of such controversial parties. Using data from the European Social Survey (2002-2018) and panel data from the Netherlands, we investigate how nativists' and non-nativists' SWD depends on mainstream parties' strategies towards PRR parties. We show that the effect is asymmetrical: at moments of inclusion nativists become substantially more satisfied with democracy, while such satisfaction among non-nativists decreases less or not at all. This pattern, which we attribute to Easton's 'reservoir of goodwill', that is, a buffer of political support generated by a track-record of good performance and responsiveness, can account for the seemingly contradictory increase in SWD in many Western European countries in times of populism.
\end{abstract}

Keywords: satisfaction with democracy; populist radical right; nativism; Western Europe

\section{Introduction}

During the last decades, populist radical right parties (PRR parties) have persistently scored electoral successes in advanced democracies. This process has culminated with PRR parties joining governments as coalition partners (e.g., Austria, Hungary, Finland, and Norway) or as supporters of government (e.g., Denmark and the Netherlands) in many countries. The success of PRR parties has motivated commentators within and outside of academia to argue that liberal democracy faces a legitimacy crisis, as voters are allegedly losing confidence in democracy (e.g., Pharr \& Putnam 2000; Dalton 2004; Foa \& Mounk, 2016, 2017).

Research also shows that both PRR voters and citizens with anti-immigrant attitudes are less satisfied with the way democracy works and express less confidence in political institutions than other voters (Lubbers et al., 2002; Belanger \& Aarts, 2006; McLaren, 2015, 2012a, 2012b; Rooduijn, 2018). PRR parties have even been shown to fuel democratic discontent in some circumstances, as their voters pick up the parties' anti-elite rhetoric (e.g., Rooduijn et al., 2016; Harteveld et al., 2017; Hooghe \& Dassonneville, 2018). Furthermore, citizens opposing the policies of PRR parties (Moffitt, 2018) might lose heart with democracy too as PRR parties gain ground. All of this predicts that levels of political support should decline across Europe in tandem with the increasing support for PRR parties among the electorates in many countries. Puzzlingly, this does not bear 
out in aggregate patterns. In fact, discontent with the way democracy works has decreased in most West European democracies during the last decades (Linde \& Dahlberg, 2016; van Ham \& Thomassen, 2017). Even more puzzling, this has most prominently been the case in countries where PRR parties have enjoyed some of their most spectacular successes, including Austria, Denmark, and Finland. This suggests that the relation between PRR party success and satisfaction with democracy (SWD) is more complex than is often assumed.

We argue and show that this relation can be better understood if we take two factors into account. First, by making a distinction between nativists and non-nativists. Nativism encompasses the belief that non-native groups and ideas constitute a threat to the nation state and the social cohesion of a society (Mudde, 2007). Second, by looking at the different strategies employed by mainstream parties toward PRR parties: inclusion or exclusion. By inclusion, we mean the formal or informal participation of the PRR party in government. In the most general terms, it would be plausible to assume that inclusion strategies damage SWD among non-nativists but boost it among nativists. The reverse seems likely to be true for exclusion strategies. However, crucially, we argue that there is good reason to expect this pattern to be asymmetrical. Most importantly, Easton's (1965) notion of a 'reservoir of goodwill' suggests that more diffuse support can stay afloat after having been generated by good performance and responsiveness. Given non-nativists' generally higher levels of satisfaction of democracy, this might shield it from decreasing under conditions of PRR inclusion (even though their more specific support for the government is likely to be very low). We provide evidence that this asymmetry explains the net rise in SWD in European democracies despite the wave of PRR success.

We test our argument by exploring the effect of (formal and informal) coalition inclusion of PRR parties on public satisfaction with both government and democracy, among nativists and non-nativists, using data from the European Social Survey (ESS) from 2002 to 2018. We then replicate our analysis with stronger internal validity using panel data in the Netherlands collected before, during, and after the inclusion of the Party for Freedom (PVV) as the informal but high-profile support partner of a right-wing coalition government.

Not very surprisingly, we find that nativists across countries tend to increase their satisfaction with the government (SWG) if it includes, or cooperates with, PRR parties - regardless if they vote for PRR parties or not - while non-nativists lose satisfaction if this happens. However, in line with the theoretical expectation, the effects of inclusion on SWD are less symmetrical. Inclusion of PRR parties boosts nativists' SWD more strongly than it hurts satisfaction among non-nativists. We replicate this finding with individual-level panel data from the Netherlands.

Our findings suggest, first, that SWD is shielded from short-term disappointments by a 'reservoir' built up over a longer period. Second, it suggests that nativists see PRR parties as their champions regardless of whether they vote for these parties or not. Third, it suggests that previous studies that have found that PRR parties fuel their voters' discontent must be put into context: it is only when they are in opposition they do so. When they are in a ruling position, they actually reduce their voters' (and many other voters') discontent. Fourth, it suggests that inclusion of PRR parties will likely increase SWD in the electorate as a whole - at least in the short term. However, because our sample does not cover long-term inclusion of PRR parties, it remains to be seen whether SWD among non-nativists would endure such prolonged PRR inclusion.

\section{Theory: a model of political support and mainstream party responses to radical right parties' electoral successes}

Our starting point is simple yet overlooked in the previous research on the relationship between the growth of PRR parties and political trust and support. Within a representative democratic system, feelings of ideological underrepresentation among a substantial share of citizens should ideally be channelled either by a policy shift by an established party or by the emergence of a new 
challenger party that politicizes the issue at stake. Elections thus function as a vehicle for preference aggregation and democratic responsiveness. However, if preferences are consistently not translated into policies (or at least given attention), then - directly or indirectly - the political system will be perceived as unresponsive by the group of policy excluded citizens, who will become more discontent (Stecker \& Tausenpfund, 2016).

Indirect evidence for this mechanism is provided by studies showing that citizens become more satisfied with democracy when their favoured parties win more votes, more legislative seats, and more cabinet seats (Anderson et al., 2005; Singh, 2014; Blais et al., 2017). Distance between citizens and governing parties on the left-right dimension has also been shown to negatively affect political support (Ezrow \& Xezonakis, 2011; Dahlberg \& Holmberg, 2014). In short, citizens who do not feel represented are more likely to be dissatisfied with the way democracy works (Dahlberg et al., 2016).

It has been suggested that this is what has happened in relation to citizens' concerns over immigration in Europe. It is a well-known fact that there exists a negative relationship between anti-immigrant attitudes and political trust among European publics (McLaren, 2016, 2015, 2012a, 2012b; Citrin et al., 2014). Citizens who are concerned about immigration feel that the political system 'has sold out the public by failing to protect the national community from the potentially disruptive and divisive force of immigration' if politicians do not listen to their concerns and reduce immigration (McLaren, 2012b: 205). There is some evidence for this mechanism: the negative association between anti-immigration attitudes and political trust is stronger in countries with a long history of immigration, suggesting actual levels of diversity matter for the extent to which immigration sceptics feel let down by the political system (McLaren, 2012b). Similarly, others have shown that the negative relationship between anti-immigrant attitudes and political trust is stronger in countries that have implemented multicultural integration policies than in countries with more assimilatory policies (Citrin et al., 2014; McLaren, 2016). In both cases, the argument is that the unwillingness of established parties to meet demands for stricter immigration and integration policies has resulted in lower levels of political trust among immigration critics, when they feel that they have no alternative to vote for. However, by now there is ample variation in such willingness - that is, in the extent to which mainstream parties actually cater to the views of nativist voters (Heinze, 2018). This is most vividly illustrated by a growing set of coalition participation with PRR parties. We expect this development to upset the relation between nativism and political trust.

We therefore hypothesize that established parties' reactions to the successes of PRR parties affect satisfaction levels in terms of general democratic performance as well as government support. In this respect, we are not only interested in the effect of political inclusion of PRR parties among their voters (which in most countries is a more restricted group) but rather among all voters holding nativist views - in our study operationalized as citizens who are critical towards immigration in general. ${ }^{1}$ The reason is that the established parties' reactions are seen as cues to whether or not the 'system' takes their concerns seriously. If established parties respond by isolating the PRR parties, nativists will likely feel neglected by the system and respond with discontent. By contrast, a strategy of inclusion may thus function as a cue to nativists that the political system is responsive to their concerns over immigration. At the same time, it sends the opposite message to non-nativists, who might lose heart with democracy, since it is giving in to policies they strongly disagree with, or even perceive as overstepping legal or moral boundaries (Blinder et al., 2013).

Of course, responses to PRR parties may take many different forms. Exclusionary strategies include (but are not limited to) party bans, prosecution of party leaderships, and cordons sanitaires, ignoring the parties or engaging with them in political debate and condemning their policy proposals (e.g., Meguid, 2005). All these responses have in common that they (to varying degrees) signal

\footnotetext{
${ }^{1}$ As a concept, nativism is broader than merely an anti-immigration attitude, but this is the dominant aspect of it in the Western European context, as well as the only way it can be operationalized over time using existing large-scale survey data.
} 
distance to the PRR parties. Admittedly, some responses are much harsher - and likely to create more discontent among nativists - than others. But historically it is fair to say that established parties have treated PRR parties in Western Europe differently from how they have treated other political opponents. Therefore, it is reasonable to assume that inclusion strategies mean a radical break with the past in most countries in Western Europe, and that nativists will react accordingly. ${ }^{2}$

Inclusion may also take different forms. It can mean government participation. It can also mean an agreement according to which the PRR party supports the government but does not become a part of it. We define both scenarios as inclusion, given that both mean that mainstream parties acknowledge the PRR party as a suitable partner. In addition, inclusion strategies can exist at the national, the regional, and the local level. We have chosen to concentrate on the national level, as we deem national elites' responses to be more salient than regional and local elites' responses - at least for SWD and SWG at the national level. However, we do not rule out effects of exclusion and inclusion strategies also at the regional and local levels.

Below we discuss the effects of inclusion strategies for nativists and non-nativists in turn, suggesting they might be asymmetrical. In that respect, we distinguish between effects on specific and more diffuse objects of support (Easton, 1975; Norris, 1999). It is important to note beforehand that nativism is a continuous attitude (both theoretically and in our empirical models) with no obvious cut-off point. Whenever we speak about effects for 'nativists' and 'non-nativists' we are using this as shorthand to discuss how citizens might react to different degrees depending on their level of nativism.

\section{The expected effect of inclusion on nativists}

We expect that when a PRR party is being included, nativists will become more satisfied, or less discontented, with the performance of the political system in general. Most importantly, when established parties discontinue their isolation strategies, nativists will perceive the political system to be more responsive to their concerns about immigration. This effect should be immediate (to the inclusion) and not contingent on mainstream parties implementing policies or PRR parties changing their behaviour. Thus, we expect inclusion to lead to an increase in satisfaction with the way democracy works among nativists and PRR voters. However, inclusion should have a stronger effect on more specific types of support, as it is likely that opposition parties will adhere to their exclusion strategies and criticize the government parties for terminating their exclusion strategies. We thus expect the positive effect of inclusion to be stronger when it comes to SWG performance.

There is also a second reason for assuming that a strategy of inclusion will increase nativists' satisfaction in the shorter term, namely that included PRR parties are likely to moderate their antielite rhetoric - and hence stop promoting discontent among their sympathizers (Rooduijn et al., 2016; Hooghe \& Dassonneville, 2018) - when they start collaborating with (some) established parties (Van Spanje \& Van Der Brug, 2007; cf. Akkerman \& Rooduijn, 2015). Again, we suggest that the effect will be stronger for SWG performance, as the PRR parties primarily must tone down their criticism of their coalition partners in such circumstances. They may even start talking positively about them, which - if we are to believe the literature on party cues - should result in higher levels of government satisfaction among their sympathisers. However, there is also a chance that the PRR parties will start to speak more positively of the political system as a whole once they have been included by parts of it.

A strategy of inclusion may also increase nativists' satisfaction in the longer term if mainstream parties adopt stricter immigration policies (and other policies that nativists appreciate). Although they can do so without including PRR parties, we expect adoption of stricter immigration policies to have a stronger effect if PRR parties are included, as PRR parties otherwise can undermine the

\footnotetext{
${ }^{2}$ In theory, it would be interesting to test whether the severity of exclusion strategies has implications for the inclusion effect. However, we have too few cases of inclusion to test interactions effects with previous strategies of exclusion empirically.
} 
credibility of the new policies. This problem is amplified by the fact that immigration is decided not only by a country's immigration policies but also by exogenous supply factors (such as the 2015 refugee crisis). Hence, there is often leeway for populist parties to blame established parties for not being restrictive enough.

We thus propose a model in which nativists become less politically satisfied in countries where the established parties employ a strategy of excluding and isolating PRR parties, and more satisfied in countries where (some) established parties collaborate with PRR parties. We remain agnostic about the time frame of the effect, as the proposed mechanisms suggest both short- and long-term effects and our data make it difficult to separate between them. Hence, we propose the following hypotheses regarding nativist voters:

HYPOTHESIS 1a: When established parties employ a strategy of inclusion towards PRR parties, nativists will become more satisfied with the way democracy works.

HYPOTHESIS 1b: When established parties employ a strategy of inclusion towards PRR parties, nativists will become more satisfied with the performance of the government.

\section{The expected effects of inclusion on non-nativists}

Nativist voters are, however, only one side of the coin. Aggregate patterns of political satisfaction are also affected by how the PRR parties' opponents (i.e., non-nativists) react when PRR parties are included. It may be tempting to assume that non-nativists will react in the opposite way to how nativist voters react, that is, becoming less satisfied. After all, opponents of PRR parties often have strong reasons to detest the parties and their policies. The possibility that opponents of PRR parties will become less satisfied suggests something like a zero-sum game, where inclusion strategies that increase satisfaction among nativist voters decrease satisfaction among the opponents. We believe this to be true for government satisfaction. Inclusion strategies, and the signal of a switch from liberal to strict immigration policies that they send, will likely lower SWG among opponents of PRR parties when they are no longer policy represented.

However, it is less clear how inclusion strategies will affect satisfaction among opponents of PRR parties. Since SWD is a less specific type of satisfaction, it could be expected to be less sensitive to policy change than SWG performance. Our expectations draw on Easton's $(1975,1965)$ notion of a 'reservoir of goodwill', which consists of diffuse public support that has been generated by periods of good performance and responsiveness. The studies discussed earlier attest that nonnativists generally have had higher levels of SWD over long periods of time. This might work as a buffer of support in periods of policy-making that they are strongly opposed to. Having been on the 'winning side' for a longer period, non-nativists may, for example, nurture hope that they will return to power after the next elections. Such asymmetrical effects among nativists and nonnativists sit well with previous findings that multiculturalists and assimilationists respond in different ways to signals from the establishment, such as prosecution of politicians for hate speech (van Spanje \& de Vreese, 2014).

Again, an additional reason for assuming weaker effects on satisfaction with the way democracy works is that PRR parties are likely to milden their anti-establishment rhetoric if they are included, which may lead to the parties becoming more respectable also in the eyes of their opponents. Taking some of the heat out of the political debate could very well mitigate the decrease in satisfaction that non-nativist voters experience when PRR parties are included. Hence,

HYPOTHESIS 2a: When established parties employ a strategy of inclusion towards PRR parties, voters holding non-nativists views will not become less satisfied with the way democracy works. 
HYPOTHESIS 2b: When established parties employ a strategy of inclusion towards PRR parties, voters holding non-nativists views will become less satisfied with the performance of the government.

The general implication of our theoretical model is that established parties' strategies of inclusion of PRR parties will have a stronger effect on SWD among nativists than among non-nativists. If the positive effect on nativists is larger than the negative effect on non-nativists, the net result is a positive effect on aggregate levels of SWD (at least in the short term) if there are equally many nativists and non-nativists in a country. If there are more nativists than non-nativists, which our data suggest is the case in some countries, the net result is an even stronger positive effect on SWD. This could help explain why there has been an increase in aggregate satisfaction with the way democracy works in countries after established parties have invited PRR parties as coalition partners. Empirical evidence of such an inclusion effect is scarce, but in a recent study of Norway, Haugsgjerd (2019) found that the gap in political support between Progress Party voters and mainstream party voters narrowed over time after the Progress Party joined a coalition government in 2013. This, in turn, might explain why sustained populist success has not been accompanied by a drastic decrease in satisfaction with democracy across Europe.

\section{Cases, data, and measurements}

We use two datasets to test our hypotheses. ${ }^{3}$ Firstly, we rely on data from the ESS 2002 to 2018. We focus on 12 West European countries in which radical right populist parties are present: Austria, Belgium, Germany, Denmark, Finland, France, UK, Greece, Italy, the Netherlands, Norway, and Sweden. We choose to exclude Central and East European countries. Immigration to these countries has been very low, and until the refugee crisis of 2015 the topic was mostly absent on the political agenda. Relatedly, the topic has not been as central to PRR parties in the region (at least not prior to 2015). In many of these countries, the mainstream right has already adopted exclusionary appeals (Bustikova \& Kitschelt, 2009). This contrasts to the 'classic' immigrant destination countries of Western Europe countries, where PRR parties have from the beginning owned the issue of immigration and have consistently captured a large share of the nativist vote.

Our approach is to use multilevel regressions to predict SWD and SWG by citizens' level of nativism. ${ }^{4}$ We do so to explore how the two attitudes correlate. We subsequently interact nativism with a dummy for inclusion. In order to be certain that the interaction actually captures the effect of changes in inclusion over time within countries, and not only cross-sectional differences in the effect of nativism between countries with and without inclusion, we follow the advice by Giesselmann and Schmidt-Catran (2019). They argue that it is necessary to control for country-specific slopes of individual-level variables to detect cross-level interaction effects in repeated cross-sectional data. To do so, we include the country means of nativism and inclusion in our models. We also interact nativism with the country mean of the inclusion variable and inclusion with the country mean nativism variable. The resulting model (which is similar to a model where nativism and inclusion are interacted with country-level dummies in an OLS framework) controls country-specific slopes for both nativism and inclusion. ${ }^{5}$ As a consequence, we can interpret the interaction between nativism and inclusion as a within-country effect - that is, as a change in the slope of nativism within countries when inclusion changes.

Secondly, in order to investigate the relationship between inclusion and support more in detail, we use a citizen panel from the Netherlands, LISS (Longitudinal Internet Studies for the Social

\footnotetext{
${ }^{3}$ The replication data are available at www.europeansocialsurvey.org and www.lissdata.nl. The replication syntax of our models is available through Dataverse at https://doi.org/10.7910/DVN/CNG7ZD.

${ }^{4} \mathrm{We}$ use mixed in Stata 16 for our models.

${ }^{5} \mathrm{We}$ also run alternative specifications with $x$ treg and OLS as recommended by Giesselmann and Schmidt-Catran (2019). These models, which are available in the appendix, essentially show the same results as the models using mixed.
} 
Sciences) waves 1-7. To our knowledge, this is the only longitudinal dataset that covers the period before, under, and after the inclusion of a PRR party: the Party for Freedom ('Partij voor de Vrijheid', or PVV). Moreover, we argue that the moment of inclusion was fairly typical within the broader universe of such inclusion moments. The party provided informal support (the only party to do so) for a coalition of the Christian democrats (CDA) and conservative liberals (VVD). This meant that PVV did not supply ministers, nor did it sign up to supporting all policy areas notably opting out of foreign policy responsibility. However, the 'informality' was limited in practice. The party leader, Geert Wilders, was heavily involved for months in the coalition formation process, obtaining several major policy concessions on immigration, and was consulted very regularly - and often used his influence to affect policy - throughout the coalition period. The PVV's support role was very controversial, especially among the CDA membership, which split down the middle over it. It was furthermore heavily mediatized in domestic and foreign media throughout the period. All in all, the controversies and high-profile policy influence on immigration policy are typical of inclusion across Western Europe. Rather than business as usual, the inclusion moment was widely perceived as a unique but controversial democratic experiment that brought nativist ideas into the centre of power. It is exactly this high-profile role of nativism that we expect to matter for citizens.

The LISS data allow us to track respondents over time and thus conduct a more stringent test of the mechanisms first explored in the wider set of countries. The LISS data are collected and hosted by CentERdata at Tilburg University in the Netherlands. The panel is based on a probability sample of households drawn from the population register. A longitudinal survey is fielded in the panel every year, covering a large variety of domains, including work, education, housing, political views, values, and personality. ${ }^{6}$

\section{Dependent variables}

In order to measure satisfaction with democratic performance, we use the question, 'On the whole, how satisfied are you with the way democracy works in [country]?' Even though it is one of the most frequently used single-item measures of political support, it should be noted that its meaning and measure have been debated (see, e.g., Canache et al., 2001; Linde \& Ekman, 2003). For example, Canache et al. (2001) show that the item - in a Latin-American context - taps multiple dimensions of support and that those dimensions tend to vary across individuals and countries. However, more recent empirical studies have demonstrated that the SWD item is a valid indicator of people's evaluations of the performance of liberal democracy, at least in Europe (Ferrín 2016; Hernández 2016). In the empirical analysis, the potential problems are somewhat remedied by the fact that we focus on only one country (the Netherlands) in the second part of the analysis. In order to capture the more specific type of support for government performance, we use the question, 'Now thinking about the (country) government, how satisfied are you with the way it is doing its job?"7

\section{Independent variables}

Our main independent variable at the system level is inclusion of PRR parties. While inclusion can take various forms, we focus empirically on the most straightforward manifestation of this: formal

\footnotetext{
${ }^{6}$ More information about the ESS data can be found at: www.europeansocialsurvey.org, while detailed information about the LISS panel can be found at: www.lissdata.nl.

${ }^{7}$ In the ESS, for both variables, the response option is a bipolar 11-point scale with the end labels 0: 'extremely dissatisfied' and 10: 'extremely satisfied'. In LISS, satisfaction with democracy is measured on an 11-point scale from 0 ('very dissatisfied') to 10 ('very satisfied'). Satisfaction with government is measured by the question, 'How satisfied or dissatisfied are you, generally speaking, about what the government has done lately?' Response options range from 0 ('very dissatisfied') to 5 ('very satisfied').
} 
Table 1. Instances of inclusion, 2002-2018

\begin{tabular}{|c|c|c|c|c|}
\hline Country & Party & Period of inclusion & ESS waves & Note \\
\hline Austria & $\begin{array}{l}\text { Freiheitliche partei } \\
\text { Österreichs (FPÖ) }\end{array}$ & 2000-2007, 2017-2019 & $\begin{array}{l}\text { 2002, 2004, 2006, } \\
\quad 2018\end{array}$ & \\
\hline Denmark & Danske folkeparti (DF) & 2001-2011, 2015-2019 & $\begin{array}{l}2002,2004,2006 \\
2008,2010\end{array}$ & $\begin{array}{l}\text { Denmark not included in ESS after } \\
2012 .\end{array}$ \\
\hline Finland & Perussuomalaiset (PS) & 2015-2017 & 2016 & \\
\hline Italy & Lega Nord (LN)/Lega & $\begin{array}{l}\text { 2001-2006, 2008- } \\
\quad 2011,2018-2019\end{array}$ & 2002, 2018 & $\begin{array}{l}\text { Italy only included in ESS 2002, } \\
2012,2016, \text { and } 2018\end{array}$ \\
\hline Netherlands & $\begin{array}{l}\text { Partij voor de Vrijheid } \\
\text { (PVV) }\end{array}$ & 2010-2012 & 2010 & $\begin{array}{l}\text { Left the government before } \\
\text { ESS } 2012\end{array}$ \\
\hline Norway & Fremskrittspartiet (FrP) & $2013-2020$ & 2014, 2016, 2018 & \\
\hline Greece & $\begin{array}{l}\text { Anexartitoi Ellines } \\
\quad \text { (ANEL) }\end{array}$ & 2015-2019 & $\mathrm{N} / \mathrm{A}$ & $\begin{array}{l}\text { Greece not included in } \\
\text { ESS after } 2010\end{array}$ \\
\hline
\end{tabular}

and informal government inclusion. Our key variable is thus a dichotomous measure capturing formal and informal governmental collaboration including PRR parties. Formal collaboration is defined as a government coalition that includes a PRR party, and informal collaboration is when a government is ruling with active support from a PRR party. In the ESS data, moments of inclusion occur in Austria 2002-2006 and 2018, Italy 2002 and 2018, Denmark 2002-2010, the Netherlands 2010, Norway 2014-2018, and Finland 2016. Since not all countries are included in all ESS rounds, some cases of inclusion must be excluded from the analysis, for example, ANEL in Greece after 2015 and Lega Nord (Italy) between 2008 and 2011. Table 1 presents an overview of instances of inclusion from 2002 to 2018.

To test our hypotheses, we distinguish between respondents according to their level of nativism. In the ESS, we construct a nativism scale consisting of three items. It is based on respondents' responses to the following questions: 'Would you say it is generally bad or good for [country]'s economy that people come to live here from other countries?', 'Would you say that [country]'s cultural life is generally undermined or enriched by people coming to live here from other countries?', and 'made a worse or a better place to live by people coming to live here from other countries?'. All questions are scaled from 0 to 10. The items scale quite well $(\alpha=0.88)$. The composite scale was recoded to run from 0 to 10 , with 10 indicating most opposition to immigration and immigrants. In LISS, our indicator of nativism is a scale of eight items concerning immigrants and integration. Cronbach's alpha in individual waves ranged from 0.70 to $0.75 .^{8}$

As noted earlier, nativism is a continuous, latent attitude that has no obvious cut-off point distinguishing 'non-nativists' from 'nativists'. Still, for descriptive or visualization purposes it is sometimes necessary to compare distinct groups. In those cases, we compare those with low scores (5th percentile), average scores, and high scores (95th percentile). This provides a reasonable lower and upper bound without relying on outliers.

To isolate the role of nativism from purely partisan 'winner' effects, we include a dummy variable (which we denote the 'winner' dummy) with a score of 1 for those who voted for a party that afterwards ended up in government and a 0 for voters of other parties. In line with earlier research, 'winners' are expected to be more satisfied (e.g., Anderson et al., 2005). Our hypothesis would be confirmed if, net of this effect, nativists and non-nativists react differently to PRR inclusion.

\footnotetext{
${ }^{8}$ The items were: It is good if society consists of people from different cultures; It is difficult for a foreigner to be accepted in the Netherlands while retaining his/her own culture; It should be made easier to obtain asylum in the Netherlands; Legally residing foreigners should be entitled to the same social security as Dutch citizens; There are too many people of foreign origin or descent in the Netherlands; People of foreign origin or descent are not accepted in the Netherlands; Some sectors of the economy can only continue to function because people of foreign origin or descent work there; It does not help a neighbourhood if there are many people of foreign origin or descent.
} 
Given that our hypotheses start from the assumption that government inclusion might affect ideological groups differently based on past trajectories, we keep open the possibility that this is also the case for partisan groups - that is, that PRR voters (regardless of their ideology) react more strongly to inclusion than other voters. Next to the winner variable, we therefore also include an interaction between inclusion and PRR support. This captures any differential effect that government inclusion might have for PRR compared to non-PRR voters. Finally, we include controls for age, age squared, gender, and education (in years). Descriptive data for the independent and dependent variables (both ESS and LISS) are presented in Table A1 in the appendix.

\section{Results}

Given the centrality of nativism in our story, we start with a descriptive discussion of its level and trend in European public opinion, based on the ESS. We then present patterns of nativism and satisfaction. Finally, we zoom in on the case of the Netherlands to get a more detailed picture.

\section{Trends in key attitudes}

The share of citizens who agree with the statement that immigrants undermine their national culture is overall quite stable in European democracies (see Figures A1 and A2 in the appendix); if anything, it is somewhat declining. On average, the proportion of nativists in the 12 countries is about $30 \%$. The mean score on our nativism scale is also relatively stable within countries. Thus, there is little evidence for a substantial growth of nativism. Several countries, most clearly Belgium, Germany, and Norway, display a general decrease over time, while Austria and Greece have experienced an increase. The lowest levels of nativism are recorded in Sweden and the highest in Austria. In short, we find the proportion of nativists in our countries to be non-negligible and, although somewhat declining, quite stable. This indicates that this group of voters may very well have an impact on aggregated political support.

SWD and SWG in Europe: To provide an overview of our dependent variables, Figure 1 presents the trend in average SWD and SWG in the 12 countries. Instances of PRR inclusion are indicated by shading. Obviously, SWD and SWG are affected by many more factors than the interplay between PRR parties' success and political reactions, and the differences between countries in both levels and trends are large.

In several countries, levels of satisfaction have increased or remained stable over the period. Public satisfaction with the way the government is doing its job displays a very similar pattern over time, although consistently at lower levels than satisfaction with the way democracy works. Moreover, no clear relationship with PRR party inclusion is visible. This is not surprising, since we expect the effect on SWD to be different for different subgroups

The relation between nativism and satisfaction: In order to investigate how the two types of support are related to anti-immigrant sentiments, we conduct a descriptive analysis in which we predict SWD and SWG by nativism in all countries in each year. Because this yields a large number of marginal effects for each country-year combination, we present it as a figure rather than a table. In Figure 2, the y-axis represents the marginal effect of nativism on SWD (black dots) and SWG (grey dots). This means that negative values indicate that more nativism is associated with lower satisfaction while positive values signal that nativists are more satisfied. At this stage, we do not include socio-demographic controls, because we are interested in the nominal correlation between nativism and satisfaction rather than isolating a causal relation.

A first observation is that for SWD the effect is almost universally negative, meaning that more nativism is associated with less SWD. The effect on SWG is sometimes absent or positive, particularly in times when PRR parties are in government or function as a support party for the government, such as in Denmark before 2011 and in Norway after 2013. There is, in other words 

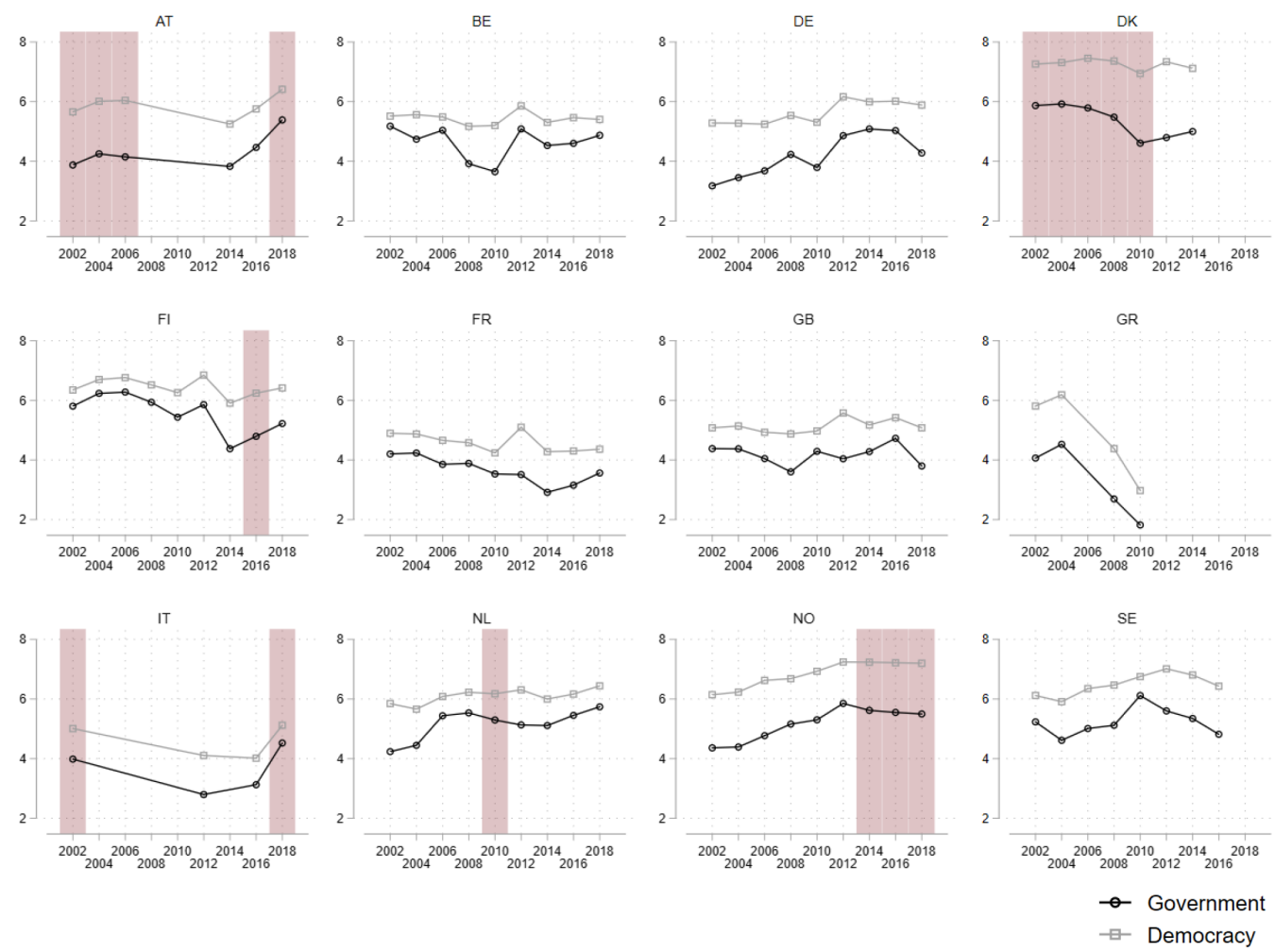

Figure 1. Satisfaction with democracy and government, 2002-2018.

Source: European Social Survey.

Note: Mean values per wave (weighted); shaded areas denote inclusion of the PRR party. Graphics scheme by Bischof (2017).

substantial variation between and within countries, indicating that the relationship seems to be related to the role played by PRR parties in the political system.

The marginal effect on SWD reached almost zero in Austria in 2002 and in 2018. In both cases, the Freedom Party (FPÖ) became a coalition partner in government. At this point, nativists were almost as satisfied with democracy as non-nativists in Austria. A similar pattern appears in Denmark, when Dansk Folkeparti (DF) supported the government between 2001 and 2011. After that, the correlation becomes more negative. In the Netherlands, the (short-lived) supporting role played by PVV in 2010 is associated with a weakening of the negative correlation, too, but to a lesser extent.

As might be expected, some of the patterns appear to be not directly related to PRR parties' inclusion, but rather indirectly, due to the adoption of more nativist stances by the mainstream right. The most obvious example is Great Britain, where a strong boost can be observed in the aftermath of the Brexit referendum, especially in terms of SWG.

Although - for the ease of the presentation - we have discussed these patterns from the point of view of a nativist voter, it is important to keep in mind that in our model the reverse might hold for non-nativists. It is an open question whether the 'discouragement' of non-nativists is as large as the 'encouragement' of non-nativists. In Figure 3, we therefore present separate predictions, based on the marginal effect, fitted for those scoring very low (5\% percentile, 'non-nativists'; black dots) and very high (95\% percentile, 'nativists'; grey dots) on the nativism variable. The figure suggests that moments of convergence between nativists and non-nativists are driven by both increasing SWD among nativists and decreasing SWD among non-nativists. 

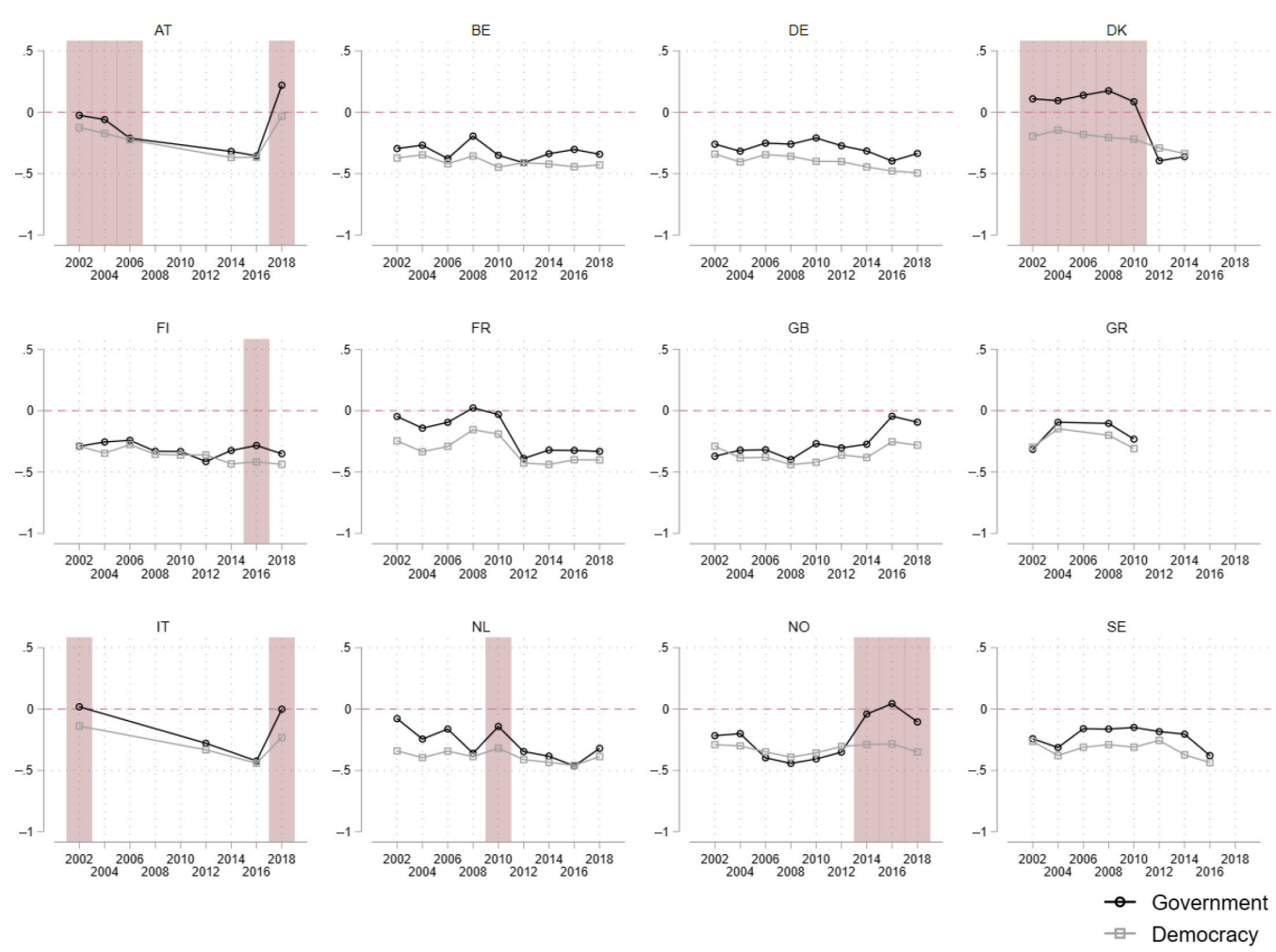

Figure 2. Marginal effect of nativism on satisfaction with government and democracy. Source: European Social Survey.

Note: Marginal effects per wave (weighted); shaded areas denote inclusion of the PRR party.

For instance, SWD increased among non-nativists and decreased among nativists in Denmark after DF stopped supporting the government in 2011. In the Netherlands, we find a convergence between nativists and non-nativists in 2010, when PVV started to act as support for the Rutte government. This divergence can be explained both by a decrease among non-nativists and an increase among nativists. Often, however, the latter is (slightly or strongly) more pronounced than the former. In Austria, the 2018 reversal was due to a relatively stronger boost among nativists, and the same is true for Italy 2018. By contrast, inclusion in Finland did not seem to affect nativists or non-nativists in any systematic way. All in all, Figure 3 suggests that inclusion matters, and to some extent asymmetrically so. We will explore this more formally below.

\section{Testing the effect of inclusion of PRR parties on SWD and SWG performance}

As a more stringent test, we use multilevel regression to explicitly model how our dummy of inclusion affects SWD and SWG. Crucially, we include an interaction with nativism, expecting that inclusion boosts SWD among citizens scoring higher on nativism, while it should not decrease SWD to the same extent among citizens with lower levels of nativism. This time we include controls for age, age squared, gender, and education (in years). In order to isolate the main relationship from a partisan winner-loser effect, we also control for voting for a 'winner' (i.e. government) party, as well as for the interaction between inclusion and voting for a PRR party more specifically. 
Satisfaction with democracy

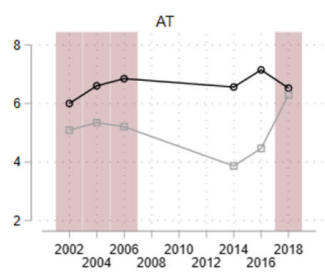

$B E$
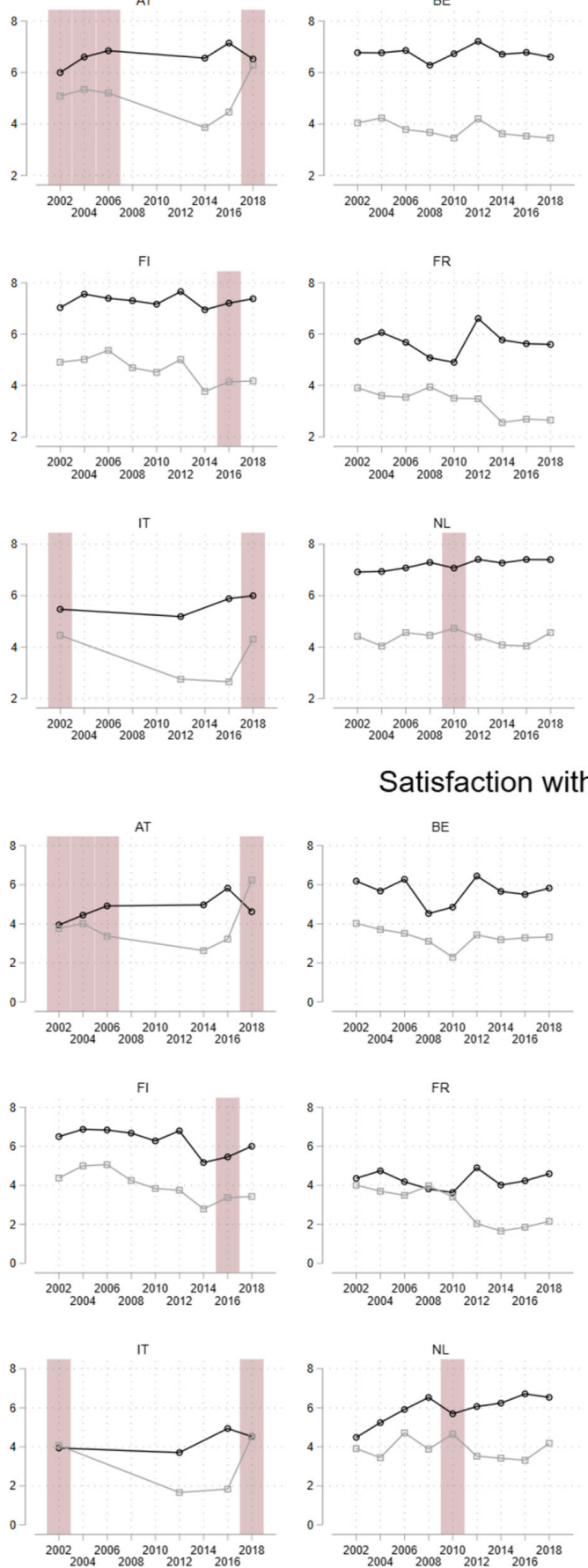

FR
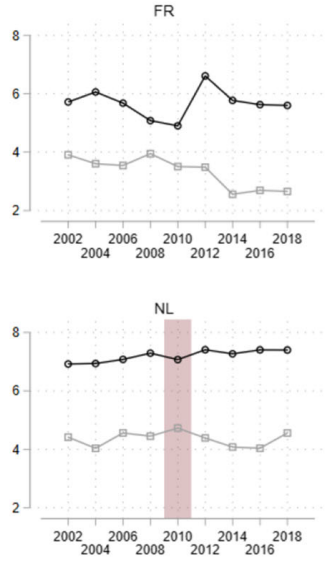

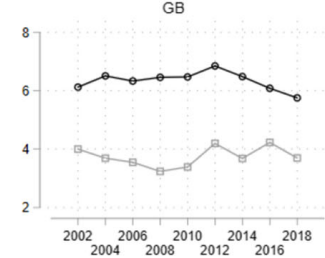

$\mathrm{DE}$

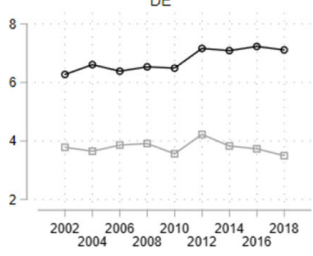

GB

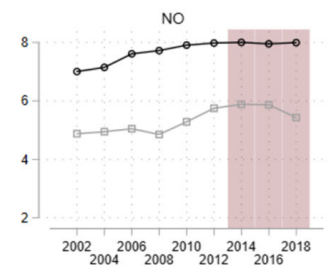

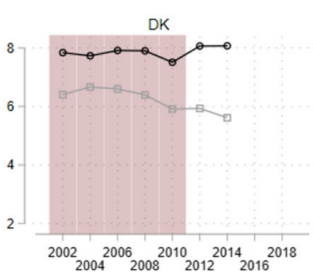

GR

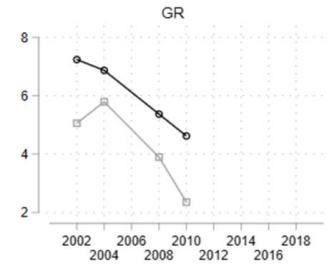

SE

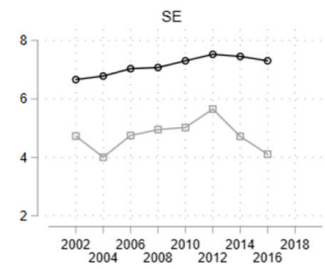

Satisfaction with government

DE
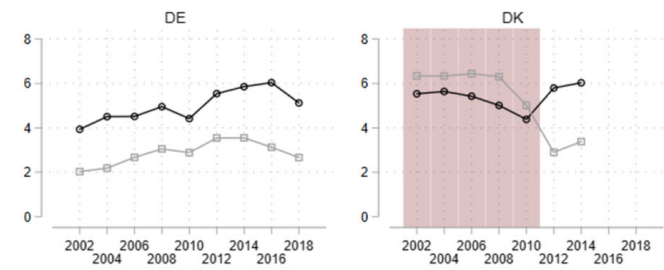

GB

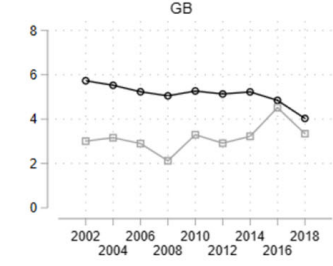

GR
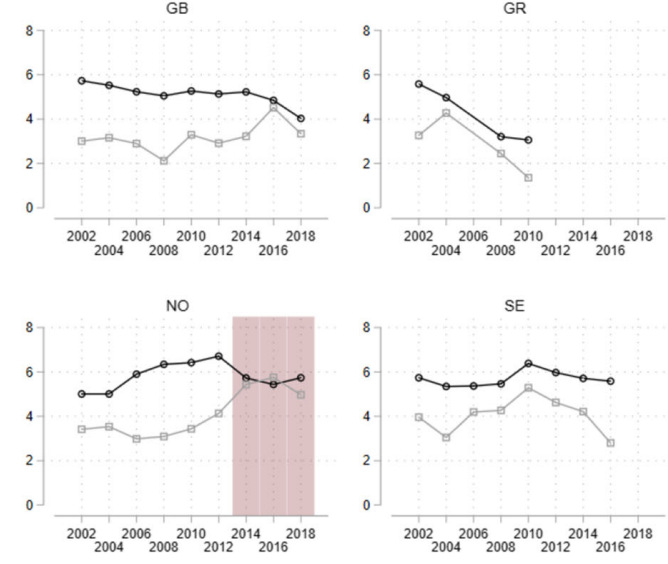

Figure 3. Satisfaction with democracy and government among nativists and non-nativists, 2002-2018.

Note: Mean values per wave (weighted); shaded areas denote inclusion of the PRR party. 
We are interested in within-country variation. We therefore include fixed effects for countries. Because our hypotheses involve a cross-level interaction, we follow the recommendations of Giesselmann and Schimdt-Catran (2019) outlined above and include the country means of all variables, as well as the necessary interactions to make sure that we isolate within country changes in the slope of nativism as inclusion changes. The full regression can be found in Table 2, with the main interaction of interest in bold.

Despite this range of controls, Table 2 confirms that there is a significant interaction between nativism and inclusion in predicting both SWD and SWG $(p<0.01)$ in all models - including the hyb5 ("hybrid") models that control both for cross-country variation in the effect of nativism and inclusion. The main interaction of interest is also visualized in Figure 4, which plots the expected level of SWG and SWD for citizens, fitted for citizens scoring low (5th percentile), average, or high (95th percentile) on the nativism index. This approach allows to gauge the lower and upper bound of the effect without relying on possibly obscure outliers.

We start our discussion with SWD. Figure 4 demonstrates that when PRR parties are being included in government there is a systematic increase in SWD among those scoring high on nativism. This increase is very substantial: almost one point (0.85) on the $0-10$ scale. As a comparison, this is larger than the entire gap in political support between the lowest and highest educated, which in our data is less than 0.8 points.

Importantly, respondents with an average or lower score on nativism do not become less satisfied with democracy. In other words, the positive inclusion effect among nativist voters is stronger than the negative inclusion effect among non-nativist voters. The fact that inclusion strategies increase SWD quite substantially among voters with an average level of nativism can explain why the net effect of inclusion on satisfaction with the way democracy works might be positive. An analysis of the marginal effects of inclusion over the full range of the nativism variable (presented in Figure A5 in the appendix) shows that SWD remains unaffected among those scoring 0, 1,2 , and 3 on nativism and is positively affected among those scoring higher.

The effects of inclusion on SWG performance are also in line with our expectations. Here, nativists and non-nativists react in a more symmetrical fashion: the former become more satisfied with the government and the latter less so, and effects in both directions are very comparable in size. Thus, when it comes to the more specific type of satisfaction with the current government, the asymmetry observed for more diffuse political support does not hold.

Taken together, this comparative analysis provides support for all our hypotheses. When established parties employ a strategy of inclusion, voters holding nativist views become more satisfied with both democracy and government ( $\mathrm{H} 1 \mathrm{a}$ and $\mathrm{H} 1 \mathrm{~b})$. Voters scoring lower on nativism become significantly less satisfied with government, while they retain their satisfaction with the way the democratic system works in general $(\mathrm{H} 2 \mathrm{a}$ and $\mathrm{H} 2 \mathrm{~b})$. Inclusion clearly affects nativists more than non-nativists when it comes to SWD but less so for SWG, where the negative effect on nonnativists is on par with the positive effect on nativists.

\section{Zooming in: inclusion and exclusion in the Netherlands}

We now turn our focus on the Netherlands, where the LISS panel data provide a possibility to conduct an analysis that allows for stronger inferences. To get a first idea of the trend in that country, Figure A3 in the appendix shows the development over time in mean SWD and SWG among respondents with levels of nativism corresponding to those used above. In line with the patterns observed in the comparative analysis, the inclusion of PVV as a support party in 2010 was accompanied by an increase in SWD among nativists and corresponding drop among nonnativists (but more strongly so in terms of SWG). The cooperation between the government and PVV continued in 2011, which was also the culmination of the Eurozone crisis, in which the Rutte government financed a bailout for Greece despite Wilders' strong objection. This could possibly explain the drop in SWD among all voters. 
Table 2. The effect of inclusion on satisfaction with democracy and government (ESS)

\begin{tabular}{|c|c|c|c|c|c|c|c|c|c|c|}
\hline & \multicolumn{5}{|c|}{ Satisfaction with democracy } & \multicolumn{5}{|c|}{ Satisfaction with government } \\
\hline & hyb1 & hyb2 & hyb3 & hyb4 & hyb5 & hyb1 & hyb2 & hyb3 & hyb4 & hyb5 \\
\hline & $\mathrm{b} / \mathrm{se}$ & $\mathrm{b} / \mathrm{se}$ & $\mathrm{b} / \mathrm{se}$ & $\mathrm{b} / \mathrm{se}$ & $\mathrm{b} / \mathrm{se}$ & $\mathrm{b} / \mathrm{se}$ & $\mathrm{b} / \mathrm{se}$ & $\mathrm{b} / \mathrm{se}$ & $\mathrm{b} / \mathrm{se}$ & $\mathrm{b} / \mathrm{se}$ \\
\hline Nativism & $\begin{array}{l}-0.313^{\star \star \star} \\
(0.003)\end{array}$ & $\begin{array}{l}-0.311^{\star \star \star} \\
(0.011)\end{array}$ & $\begin{array}{l}-0.319^{\star \star \star} \\
(0.014)\end{array}$ & $\begin{array}{l}-0.308^{\star \star \star} \\
(0.010)\end{array}$ & $\begin{array}{l}-0.319^{\star \star \star} \\
(0.014)\end{array}$ & $\begin{array}{l}-0.214^{\star \star \star} \\
(0.003)\end{array}$ & $\begin{array}{l}-0.252^{\star \star \star} \\
(0.018)\end{array}$ & $\begin{array}{l}-0.244^{\star \star \star} \\
(0.021)\end{array}$ & $\begin{array}{c}-0.246^{\star \star \star} \\
(0.017)\end{array}$ & $\begin{array}{l}-0.244^{\star \star \star} \\
(0.021)\end{array}$ \\
\hline Inclusion & $\begin{array}{l}0.287^{\star \star \star} \\
(0.021)\end{array}$ & $\begin{array}{r}-0.346 \\
(0.189)\end{array}$ & $\begin{array}{c}-0.186 \\
(0.193)\end{array}$ & $\begin{array}{c}-2.617^{\star \star} \\
(0.909)\end{array}$ & $\begin{array}{c}-2.713^{\star \star} \\
(0.868)\end{array}$ & $\begin{array}{l}0.337^{\star \star \star} \\
(0.021)\end{array}$ & $\begin{array}{l}-0.916^{\star \star \star} \\
(0.213)\end{array}$ & $\begin{array}{l}-0.977^{\star \star \star} \\
(0.206)\end{array}$ & $\begin{array}{c}-4.102 \\
(2.539)\end{array}$ & $\begin{array}{c}-4.119 \\
(2.545)\end{array}$ \\
\hline Nativism (country mean) & $\begin{array}{c}-0.539 \\
(0.324)\end{array}$ & $\begin{array}{l}-0.720^{\star \star \star} \\
(0.174)\end{array}$ & $\begin{array}{r}-0.581^{*} \\
(0.254)\end{array}$ & $\begin{array}{r}-0.596^{\star} \\
(0.283)\end{array}$ & $\begin{array}{r}-0.584^{\star} \\
(0.286)\end{array}$ & $\begin{array}{l}-0.842^{\star \star \star} \\
(0.218)\end{array}$ & $\begin{array}{l}-0.684^{\star \star \star} \\
(0.031)\end{array}$ & $\begin{array}{l}-0.524^{\star \star} \\
(0.165)\end{array}$ & $\begin{array}{r}-0.518^{\star} \\
(0.204)\end{array}$ & $\begin{array}{r}-0.517^{\star} \\
(0.203)\end{array}$ \\
\hline Inclusion (country mean) & $\begin{array}{c}0.755 \\
(0.463)\end{array}$ & $\begin{array}{c}-8.637 \\
(7.385)\end{array}$ & $\begin{array}{c}0.111 \\
(0.800)\end{array}$ & $\begin{array}{c}0.318 \\
(0.816)\end{array}$ & $\begin{array}{c}-0.251 \\
(0.857)\end{array}$ & $\begin{array}{l}0.23 \\
(0.312)\end{array}$ & $\begin{array}{c}-26.950^{\star \star \star} \\
(1.291)\end{array}$ & $\begin{array}{l}-0.05 \\
(0.478)\end{array}$ & $\begin{array}{c}-0.447 \\
(0.479)\end{array}$ & $\begin{array}{c}-0.412 \\
(0.608)\end{array}$ \\
\hline Age & $\begin{array}{l}0.004^{\star \star *} \\
(0.000)\end{array}$ & $\begin{array}{l}0.004^{\star *} \\
(0.001)\end{array}$ & $\begin{array}{l}0.004^{\star \star} \\
(0.001)\end{array}$ & $\begin{array}{l}0.004^{\star *} \\
(0.001)\end{array}$ & $\begin{array}{l}0.004^{\star *} \\
(0.001)\end{array}$ & $\begin{array}{l}0.006^{\star \star *} \\
(0.000)\end{array}$ & $\begin{array}{l}0.006^{\star \star *} \\
(0.001)\end{array}$ & $\begin{array}{l}0.006^{\star \star *} \\
(0.001)\end{array}$ & $\begin{array}{l}0.006^{\star \star \star} \\
(0.001)\end{array}$ & $\begin{array}{l}0.006^{\star * *} \\
(0.001)\end{array}$ \\
\hline Age (country mean) & $\begin{array}{c}-0.289 \\
(0.154)\end{array}$ & $\begin{array}{l}-0.601^{\star \star \star} \\
(0.115)\end{array}$ & $\begin{array}{c}-0.219 \\
(0.179)\end{array}$ & $\begin{array}{c}-0.196 \\
(0.201)\end{array}$ & $\begin{array}{c}-0.187 \\
(0.204)\end{array}$ & $\begin{array}{l}-0.2 \\
(0.104)\end{array}$ & $\begin{array}{l}-0.354^{\star \star \star} \\
(0.019)\end{array}$ & $\begin{array}{c}0.027 \\
(0.106)\end{array}$ & $\begin{array}{c}0.074 \\
(0.135)\end{array}$ & $\begin{array}{c}0.079 \\
(0.134)\end{array}$ \\
\hline Female & $\begin{array}{l}0.201^{\star \star \star} \\
(0.012)\end{array}$ & $\begin{array}{l}0.208^{\star \star \star} \\
(0.035)\end{array}$ & $\begin{array}{l}0.207^{\star \star \star} \\
(0.036)\end{array}$ & $\begin{array}{l}0.208^{\star \star \star} \\
(0.035)\end{array}$ & $\begin{array}{l}0.207^{\star * \star} \\
(0.036)\end{array}$ & $\begin{array}{l}0.114^{\star \star \star} \\
(0.012)\end{array}$ & $\begin{array}{l}0.125^{\star \star \star} \\
(0.031)\end{array}$ & $\begin{array}{l}0.126^{\star \star \star} \\
(0.031)\end{array}$ & $\begin{array}{l}0.125^{\star \star \star} \\
(0.031)\end{array}$ & $\begin{array}{l}0.125^{\star \star \star} \\
(0.031)\end{array}$ \\
\hline Female (country mean) & $\begin{array}{c}-8.161 \\
(9.494)\end{array}$ & $\begin{array}{c}-28.891^{\star \star \star} \\
(4.614)\end{array}$ & $\begin{array}{l}-7.698 \\
(12.070)\end{array}$ & $\begin{array}{l}-6.543 \\
(13.501)\end{array}$ & $\begin{array}{l}-6.09 \\
(13.797)\end{array}$ & $\begin{array}{r}-10.979 \\
(6.386)\end{array}$ & $\begin{array}{c}-17.387^{\star \star \star} \\
(0.799)\end{array}$ & $\begin{array}{c}2.784 \\
(8.987)\end{array}$ & $\begin{array}{c}5.248 \\
(10.549)\end{array}$ & $\begin{array}{c}5.486 \\
(10.518)\end{array}$ \\
\hline Winner & $\begin{array}{l}0.666^{\star \star \star} \\
(0.012)\end{array}$ & $\begin{array}{l}0.582^{\star \star \star} \\
(0.091)\end{array}$ & $\begin{array}{l}0.587^{\star \star \star} \\
(0.090)\end{array}$ & $\begin{array}{l}0.581^{\star \star \star} \\
(0.092)\end{array}$ & $\begin{array}{l}0.587^{\star \star \star} \\
(0.091)\end{array}$ & $\begin{array}{l}1.296^{\star \star *} \\
(0.012)\end{array}$ & $\begin{array}{l}1.262^{\star \star \star} \\
(0.148)\end{array}$ & $\begin{array}{l}1.261^{\star \star \star} \\
(0.148)\end{array}$ & $\begin{array}{l}1.257^{\star \star \star} \\
(0.147)\end{array}$ & $\begin{array}{l}1.260^{\star \star \star} \\
(0.149)\end{array}$ \\
\hline Winner (country mean) & $\begin{array}{l}-1.75 \\
(1.614)\end{array}$ & $\begin{array}{l}-3.401^{\star \star \star} \\
(0.636)\end{array}$ & $\begin{array}{c}-1.231 \\
(2.422)\end{array}$ & $\begin{array}{c}-1.161 \\
(2.711)\end{array}$ & $\begin{array}{c}-1.138 \\
(2.781)\end{array}$ & $\begin{array}{r}-1.618 \\
(1.085)\end{array}$ & $\begin{array}{l}-0.978^{\star \star \star} \\
(0.102)\end{array}$ & $\begin{array}{l}1.57 \\
(1.443)\end{array}$ & $\begin{array}{l}1.769 \\
(1.887)\end{array}$ & $\begin{array}{c}1.811 \\
(1.859)\end{array}$ \\
\hline Education (years) & $\begin{array}{l}0.015^{\star \star \star} \\
(0.002)\end{array}$ & $\begin{array}{l}0.016^{\star} \\
(0.008)\end{array}$ & $\begin{array}{l}0.016^{\star} \\
(0.008)\end{array}$ & $\begin{array}{l}0.017^{\star} \\
(0.008)\end{array}$ & $\begin{array}{c}0.017^{\star} \\
(0.008)\end{array}$ & $\begin{array}{l}-0.006^{\star \star \star} \\
(0.002)\end{array}$ & $\begin{array}{c}-0.007 \\
(0.008)\end{array}$ & $\begin{array}{r}-0.007 \\
(0.008)\end{array}$ & $\begin{array}{c}-0.006 \\
(0.008)\end{array}$ & $\begin{array}{c}-0.006 \\
(0.008)\end{array}$ \\
\hline $\begin{array}{l}\text { Education (years, } \\
\text { country mean) }\end{array}$ & $\begin{array}{c}0.076 \\
(0.238)\end{array}$ & $\begin{array}{l}0.014 \\
(0.147)\end{array}$ & $\begin{array}{c}-0.065 \\
(0.257)\end{array}$ & $\begin{array}{c}-0.069 \\
(0.274)\end{array}$ & $\begin{array}{c}-0.072 \\
(0.278)\end{array}$ & $\begin{array}{c}-0.022 \\
(0.160)\end{array}$ & $\begin{array}{l}0.082^{\star \star} \\
(0.028)\end{array}$ & $\begin{array}{c}-0.029 \\
(0.119)\end{array}$ & $\begin{array}{c}-0.044 \\
(0.148)\end{array}$ & $\begin{array}{c}-0.047 \\
(0.147)\end{array}$ \\
\hline Nativism $\times$ inclusion & & $\begin{array}{l}0.143^{\star \star \star} \\
(0.039)\end{array}$ & $\begin{array}{r}0.111^{\star} \\
(0.045)\end{array}$ & $\begin{array}{l}0.127^{\star \star \star} \\
(0.038)\end{array}$ & $\begin{array}{l}0.081^{\star} \\
(0.040)\end{array}$ & & $\begin{array}{l}0.287^{\star \star \star} \\
(0.046)\end{array}$ & $\begin{array}{l}0.300^{\star \star \star} \\
(0.049)\end{array}$ & $\begin{array}{l}0.261^{\star \star \star} \\
(0.046)\end{array}$ & $\begin{array}{l}0.269^{\star \star \star} \\
(0.060)\end{array}$ \\
\hline $\begin{array}{l}\text { (Nativism } \times \text { inclusion) } \\
\text { (country mean) }\end{array}$ & & $\begin{array}{l}1.13 \\
(1.293)\end{array}$ & & & & & $\begin{array}{l}4.420^{\star \star \star} \\
(0.237)\end{array}$ & & & \\
\hline $\begin{array}{l}\text { Nativism } \times \text { Inclusion } \\
\text { (country mean) }\end{array}$ & & & $\begin{array}{c}0.072 \\
(0.050)\end{array}$ & & $\begin{array}{l}0.103^{*} \\
(0.042)\end{array}$ & & & $\begin{array}{l}-0.05 \\
(0.049)\end{array}$ & & $\begin{array}{c}-0.019 \\
(0.060)\end{array}$ \\
\hline $\begin{array}{l}\text { Nativism (country mean) } \\
\quad \times \text { inclusion }\end{array}$ & & & & $\begin{array}{c}0.472^{*} \\
(0.219)\end{array}$ & $\begin{array}{c}0.539^{\star \star} \\
(0.202)\end{array}$ & & & & $\begin{array}{l}0.63 \\
(0.520)\end{array}$ & $\begin{array}{c}0.628 \\
(0.537)\end{array}$ \\
\hline
\end{tabular}


Table 2. (Continued)

\begin{tabular}{|c|c|c|c|c|c|c|c|c|c|c|}
\hline & \multicolumn{5}{|c|}{ Satisfaction with democracy } & \multicolumn{5}{|c|}{ Satisfaction with government } \\
\hline & hyb1 & hyb2 & hyb3 & hyb4 & hyb5 & hyb1 & hyb2 & hyb3 & hyb4 & hyb5 \\
\hline & $\mathrm{b} / \mathrm{se}$ & $\mathrm{b} / \mathrm{se}$ & $\mathrm{b} / \mathrm{se}$ & $\mathrm{b} / \mathrm{se}$ & $\mathrm{b} / \mathrm{se}$ & $\mathrm{b} / \mathrm{se}$ & $\mathrm{b} / \mathrm{se}$ & $\mathrm{b} / \mathrm{se}$ & $\mathrm{b} / \mathrm{se}$ & $\mathrm{b} / \mathrm{se}$ \\
\hline PRR vote & & $\begin{array}{l}-0.494^{\star \star \star} \\
(0.088)\end{array}$ & $\begin{array}{l}-0.623^{\star \star \star} \\
(0.092)\end{array}$ & $\begin{array}{l}-0.501^{\star \star \star} \\
(0.083)\end{array}$ & $\begin{array}{l}-0.619^{\star \star \star} \\
(0.090)\end{array}$ & & $\begin{array}{r}-0.233 \\
(0.177)\end{array}$ & $\begin{array}{r}-0.414^{*} \\
(0.177)\end{array}$ & $\begin{array}{r}-0.295^{\star} \\
(0.129)\end{array}$ & $\begin{array}{r}-0.406^{*} \\
(0.170)\end{array}$ \\
\hline $\begin{array}{l}\text { PRR vote (country } \\
\text { mean) }\end{array}$ & & $\begin{array}{l}-6.642 \\
(3.646)\end{array}$ & $\begin{array}{l}5.613 \\
(5.610)\end{array}$ & $\begin{array}{c}6.283 \\
(6.054)\end{array}$ & $\begin{array}{c}6.607 \\
(6.166)\end{array}$ & & $\begin{array}{l}-5.490^{\star * \star} \\
(0.602)\end{array}$ & $\begin{array}{l}3.109 \\
(3.106)\end{array}$ & $\begin{array}{l}3.903 \\
(3.902)\end{array}$ & $\begin{array}{l}3.9 \\
(3.944)\end{array}$ \\
\hline RRvote $\times$ inclusion & & & $\begin{array}{c}-0.092 \\
(0.233)\end{array}$ & $\begin{array}{c}0.095 \\
(0.265)\end{array}$ & $\begin{array}{c}-0.012 \\
(0.213)\end{array}$ & & & $\begin{array}{c}0.104 \\
(0.343)\end{array}$ & $\begin{array}{c}0.338 \\
(0.349)\end{array}$ & $\begin{array}{c}0.176 \\
(0.305)\end{array}$ \\
\hline $\begin{array}{l}\text { (Nativism } \times \text { inclusion }) \\
\text { (country mean) }\end{array}$ & & $\begin{array}{l}76.639^{\star \star \star} \\
(21.134)\end{array}$ & & & & & $\begin{array}{l}101.259^{\star * \star} \\
(3.666)\end{array}$ & & & \\
\hline $\begin{array}{l}\text { RRvote } \times \text { inclusion } \\
\text { (country mean) }\end{array}$ & & & $\begin{array}{c}0.562 \\
(0.460)\end{array}$ & & $\begin{array}{c}0.535 \\
(0.412)\end{array}$ & & & $\begin{array}{c}0.608 \\
(0.400)\end{array}$ & & $\begin{array}{c}0.594 \\
(0.367)\end{array}$ \\
\hline $\begin{array}{l}\text { RRvote (country mean) } \\
\times \text { inclusion }\end{array}$ & & & & $\begin{array}{c}2.015 \\
(2.607)\end{array}$ & $\begin{array}{c}2.162 \\
(2.475)\end{array}$ & & & & $\begin{array}{l}4.425 \\
(4.162)\end{array}$ & $\begin{array}{c}4.542 \\
(4.109)\end{array}$ \\
\hline Intercept & $\begin{array}{r}26.680^{*} \\
(12.215)\end{array}$ & $\begin{array}{l}54.230^{\star \star \star} \\
(7.854)\end{array}$ & $\begin{array}{c}24.613 \\
(14.782)\end{array}$ & $\begin{array}{l}22.97 \\
(16.603)\end{array}$ & $\begin{array}{c}22.353 \\
(16.950)\end{array}$ & $\begin{array}{l}24.606^{\star \star} \\
(8.216)\end{array}$ & $\begin{array}{l}33.111^{\star \star \star} \\
(1.349)\end{array}$ & $\begin{array}{c}4.265 \\
(9.805)\end{array}$ & $\begin{array}{c}0.839 \\
(11.946)\end{array}$ & $\begin{array}{c}0.494 \\
(11.884)\end{array}$ \\
\hline \multicolumn{11}{|l|}{ Random intercept } \\
\hline Variance (level-2) & $\begin{array}{c}0.175 \\
(0.072)\end{array}$ & $\begin{array}{c}0.032 \\
(0.012)\end{array}$ & $\begin{array}{c}0.194 \\
(0.062)\end{array}$ & $\begin{array}{c}0.229 \\
(0.074)\end{array}$ & $\begin{array}{c}0.240 \\
(0.078)\end{array}$ & $\begin{array}{c}0.079 \\
(0.032)\end{array}$ & $\begin{array}{c}0.001 \\
(0.000)\end{array}$ & $\begin{array}{c}0.070 \\
(0.024)\end{array}$ & $\begin{array}{c}0.100 \\
(0.034)\end{array}$ & $\begin{array}{c}0.099 \\
(0.033)\end{array}$ \\
\hline Variance (level-1) & $\begin{array}{c}4.187 \\
(0.017)\end{array}$ & $\begin{array}{c}4.047 \\
(0.342)\end{array}$ & $\begin{array}{c}4.045 \\
(0.343)\end{array}$ & $\begin{array}{c}4.044 \\
(0.343)\end{array}$ & $\begin{array}{c}4.040 \\
(0.344)\end{array}$ & $\begin{array}{c}4.379 \\
(0.018)\end{array}$ & $\begin{array}{c}4.310 \\
(0.220)\end{array}$ & $\begin{array}{c}4.308 \\
(0.220)\end{array}$ & $\begin{array}{c}4.303 \\
(0.225)\end{array}$ & $\begin{array}{c}4.302 \\
(0.225)\end{array}$ \\
\hline $\mathrm{N}$ (respondents) & 119,544 & 119,540 & 119,540 & 119,540 & 119,540 & 119,605 & 119,601 & 119,601 & 119,601 & 119,601 \\
\hline $\mathrm{N}$ (countries) & 12 & 12 & 12 & 12 & 12 & 12 & 12 & 12 & 12 & 12 \\
\hline
\end{tabular}

Note: ${ }^{* *} P<0.001 ;{ }^{* *} P<0.01 ;{ }^{*} P<0.05$.

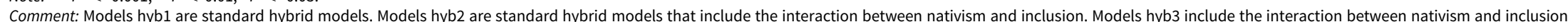

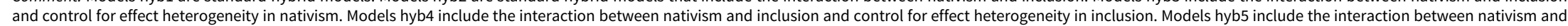
inclusion and control for effect heterogeneity in both nativism and inclusion.

Source: European Social Survey (ESS) 

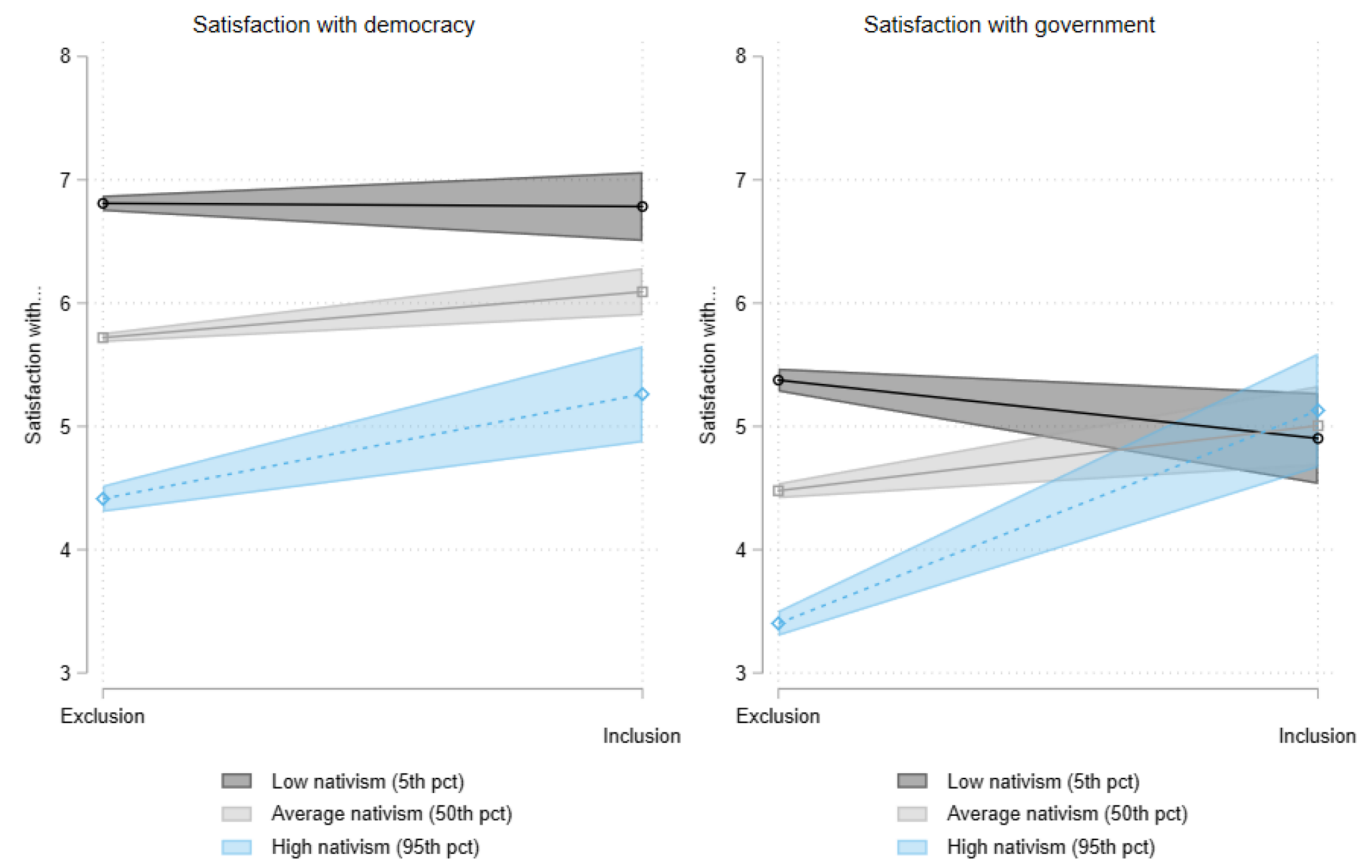

Figure 4. The effect of inclusion on satisfaction with democracy and government (ESS). Source: European Social Survey.

Note: Based on models hyb3 in Table 2.

Of course, these numbers still reflect aggregate trends, which might be subject to various confounders. Fortunately, the panel structure of the Dutch data allows us to track individual respondents over time, thus making it possible to draw stronger inferences about the effect of moments of inclusion on SWD and SWG. Table 3 shows the result of a panel regression. We use random effects at the respondent level in order to control for the possibility that the variation in SWD is driven by differences between respondents rather than within them (Hamaker et al., 2015). A fixed effects model would have been preferable if it was not for the fact that FE models with a lagged dependent variable provide biased estimates when used with short panels, $\mathrm{T}<15$ (Lindgren, 2006). SWD and SWG are predicted by their lags as well as nativism, PVV support, and a dummy for Wilders' inclusion. The latter takes the value of 1 for the year 2010 and 2011 .

The effect of Wilders' government collaboration is interacted with both (a) the lag of nativism and (b) support for Wilders, in order to disentangle purely partisan from ideological effects. For the ease of interpretation, the results are presented graphically in Figure 5. The top graph (showing the effects on SWD) once again confirms our expectation that inclusion increases SWD among nativists.

In somewhat of a contrast to the non-significant effect found in the comparative analysis above (Figure 4), Dutch non-nativists do become significantly less satisfied with the way democracy works in a situation of inclusion. This goes against the expectation that the 'reservoir' of support 'shields' non-nativist voters. However, the drop in SWD is fully driven by the year 2011, when the Euro crisis culminated, and all voters experienced a massive drop in SWD (see Figure A3 in the appendix). If we look at the effect of inclusion only in 2010, the year the inclusion started, nonnativists were not at all experiencing a drop in SWD. That year, SWD among nativists - controlled for their previous SWD in our panel - increased a full half-point on the 0-10 scale, which can be 
Table 3. The effect of inclusion on satisfaction with democracy and government (LISS)

\begin{tabular}{|c|c|c|c|c|}
\hline & \multicolumn{2}{|c|}{ Democracy } & \multicolumn{2}{|c|}{ Government } \\
\hline & Model 1 & Model 2 & Model 3 & Model 4 \\
\hline Satisfaction with democracy (lagged) & $\begin{array}{c}0.629^{\star \star \star} \\
(0.005)\end{array}$ & $\begin{array}{c}0.629^{\star * \star} \\
(0.005)\end{array}$ & & \\
\hline Satisfaction with government (lagged) & & & $\begin{array}{c}0.435^{\star \star \star} \\
(0.005)\end{array}$ & $\begin{array}{c}0.431^{\star \star \star} \\
(0.005)\end{array}$ \\
\hline Wilders in government & $\begin{array}{c}-0.068^{\star \star \star} \\
(0.019)\end{array}$ & $\begin{array}{c}-0.412^{\star \star \star} \\
(0.075)\end{array}$ & $\begin{array}{l}-0.003 \\
(0.009)\end{array}$ & $\begin{array}{c}-0.685^{\star \star \star} \\
(0.037)\end{array}$ \\
\hline PVV vote choice & $\begin{array}{c}-0.339^{\star \star \star} \\
(0.033)\end{array}$ & $\begin{array}{c}-0.420^{\star \star \star} \\
(0.040)\end{array}$ & $\begin{array}{c}-0.259^{\star \star \star} \\
(0.016)\end{array}$ & $\begin{array}{c}-0.365^{\star \star \star} \\
(0.020)\end{array}$ \\
\hline Nativism (lagged) & $\begin{array}{c}-0.924^{\star \star \star} \\
(0.069)\end{array}$ & $\begin{array}{c}-1.132^{\star \star \star} \\
(0.084)\end{array}$ & $\begin{array}{c}-0.069^{\star} \\
(0.034)\end{array}$ & $\begin{array}{c}-0.495^{\star \star \star} \\
(0.041)\end{array}$ \\
\hline Wilders in government $\times$ PVV vote choice & & $\begin{array}{c}0.246^{\star \star \star} \\
(0.070)\end{array}$ & & $\begin{array}{c}0.316^{\star \star \star} \\
(0.034)\end{array}$ \\
\hline Wilders in government $\times$ nativism (lagged) & & $\begin{array}{c}0.626^{\star \star \star} \\
(0.144)\end{array}$ & & $\begin{array}{c}1.267^{\star \star \star} \\
(0.070)\end{array}$ \\
\hline Intercept & $\begin{array}{c}2.806^{\star \star \star} \\
(0.052)\end{array}$ & $\begin{array}{c}2.919^{\star \star \star} \\
(0.058)\end{array}$ & $\begin{array}{c}1.580^{\star \star \star} \\
(0.024)\end{array}$ & $\begin{array}{c}1.822^{\star \star \star} \\
(0.026)\end{array}$ \\
\hline N (observations) & 27,099 & 27,099 & 28,965 & 28,965 \\
\hline N (respondents) & 7860 & 7860 & 8127 & 8127 \\
\hline $\mathrm{R}^{2}$ & 0.41 & 0.41 & 0.20 & 0.22 \\
\hline
\end{tabular}

Note: ${ }^{\star \star \star} P<0.001 ;{ }^{\star \star} P<0.01 ;{ }^{\star} P<0.05$.

Source: LISS.

Note: Seven waves.

seen in Figure A4 in the appendix. The start of the inclusion thus fits the pattern found in the ESS data.

The interesting result of this regression is that both interactions exist next to each other. In other words, the increase and decrease among respectively nativists and non-nativists are not confounded by the fact that they are PVV supporters who see their party in power (which would simply replicate findings about election winners and losers). Rather, it likely (also) reflects happiness or frustration about changes in policy.

The bottom graph in Figure 5, which plots the effects of inclusion on satisfaction with the way the government does its job, shows strong reactions among both nativists and non-nativists. Indeed, the reactions are so strong in both groups that they switch positions on government satisfaction. Before inclusion, nativists are less satisfied than non-nativists with the government's performance, but after inclusion they are more satisfied than non-nativists. PVV voters react like nativists and become more satisfied with the government's performance after inclusion. However, other voters are hardly affected by the inclusion of PVV, perhaps reflecting the fact that the category also includes non-PVV supporters of the new government.

In short, our analyses at first do not suggest the asymmetry (in which inclusion increases SWD more among nativists than it decreases it among non-nativists) noted in the country-comparative analysis. At the same time, the initial impression masks a pattern in which the start of inclusion did have exactly this asymmetrical effect. However, in the second year of inclusion, when the Euro crisis had led to strains between the government and the PVV, nativists lost their newly gained SWD just as easily. ${ }^{9}$

\footnotetext{
${ }^{9}$ It is remarkable that, overall, SWD among nativists after the inclusion period is lower than before. This is a pattern that does not consistently occur in the comparative data of Figure 3. Given that PVV's inclusion ended in disharmony, this suggests that an 'inclusion breakup' that ends in a fight or feelings of betrayal prevents the formation of a 'reservoir' among nativists. However, this explanation remains tentative given a lack of sufficient cases to compare peaceful from disharmonious ends to inclusion episodes.
} 


\section{Satisfaction with democracy}
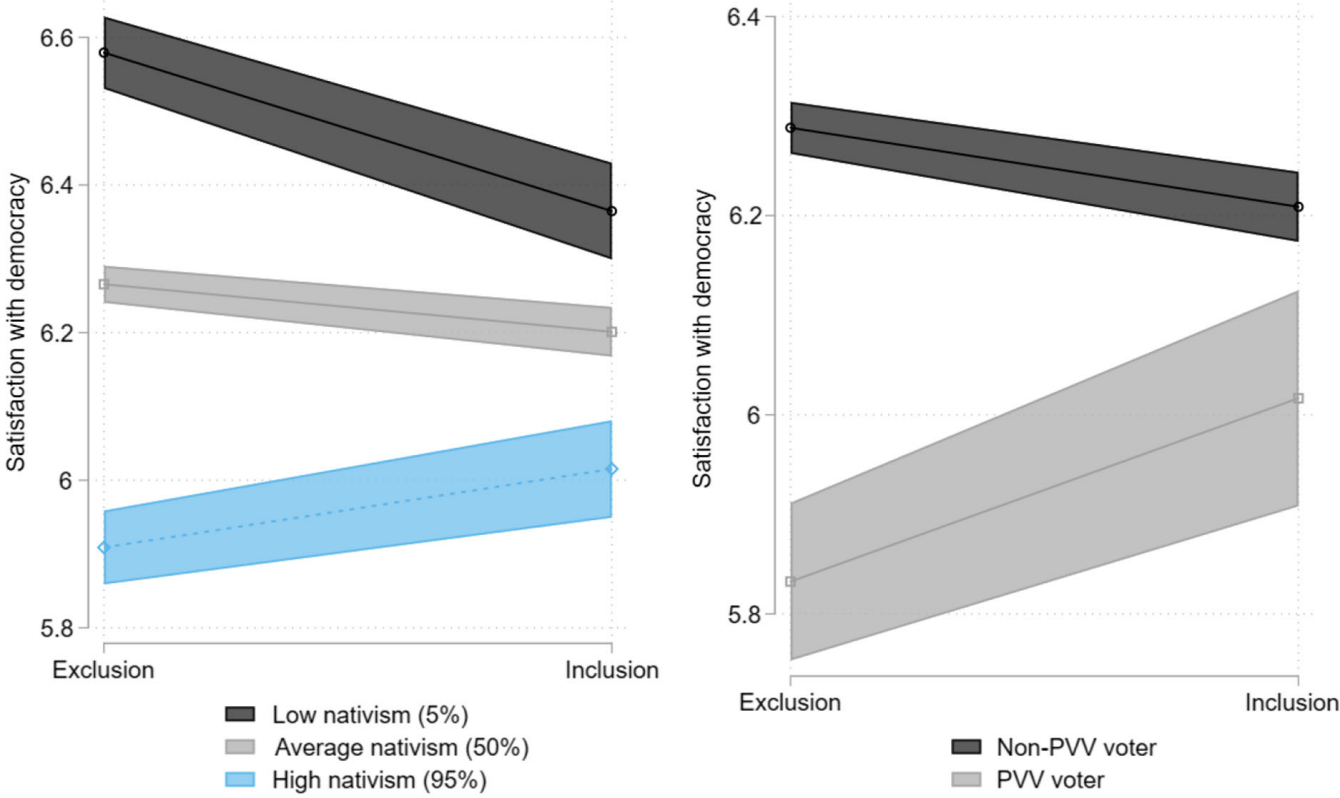

Satisfaction with government
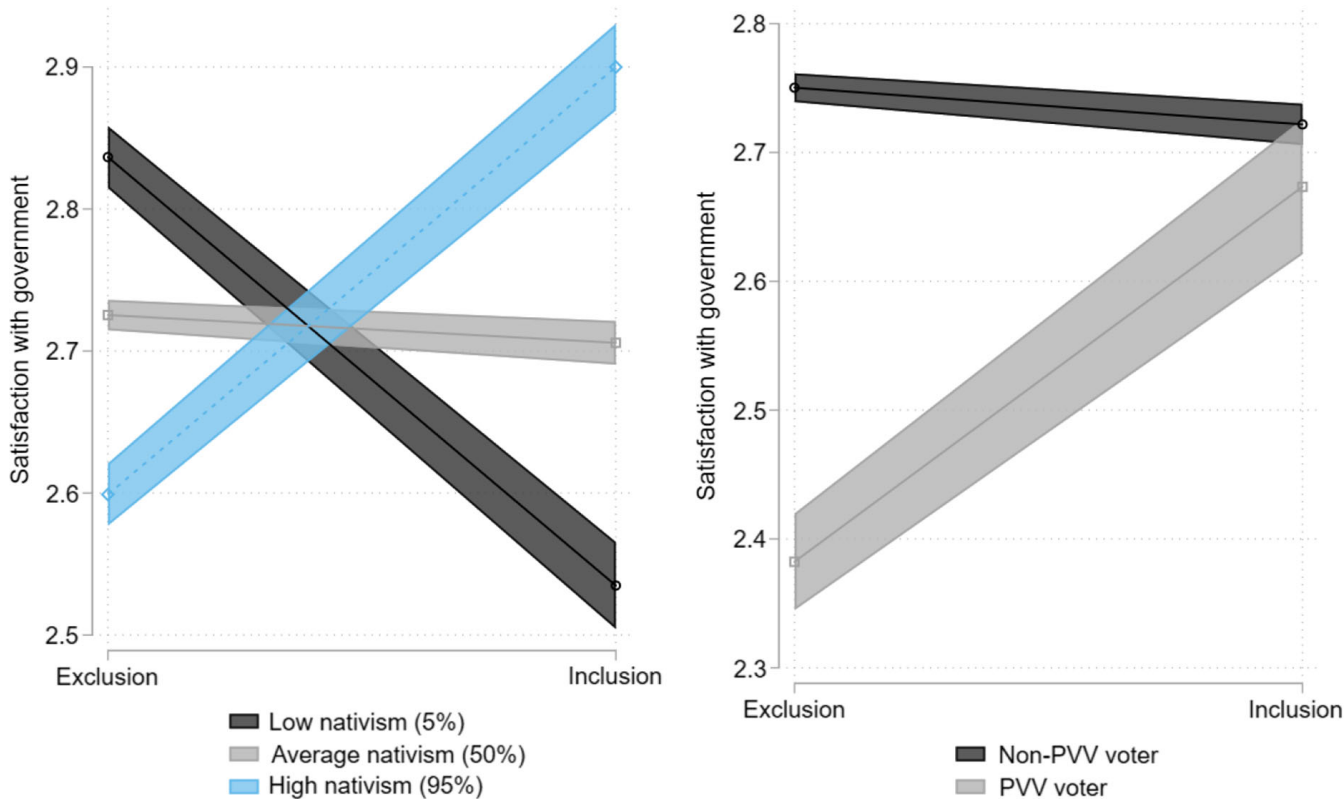

Figure 5. The effect of inclusion (2010 and 2011) on satisfaction with democracy and government ISS). Source: LISS. 


\section{Concluding remarks}

In this paper, we present an explanation to why satisfaction with the way democracy works (SWD) seemingly has increased in the wake of PRR parties' electoral successes in recent years, despite the fact that recent research shows that voters tend to become increasingly discontent with democracy after they have started to vote for PRR parties. Noting that the increase in SWD mainly seems to manifest itself in countries where PRR parties have been included in the government, or acted as support parties of the government, we argue and show that the effect of PRR parties' electoral successes on political support is contingent on whether established parties respond by including or excluding the PRR parties. If they are excluded, nativists (who constitute a substantial share of the electorates across all included countries, see Figure A1) will become increasingly discontent. However, when included, nativists become more satisfied with the way democracy works (as well as with the government's performance more specifically). While our data did not allow to disentangle mechanisms, one likely reason is that they feel that mainstream parties acknowledge their concerns and admit they are warranted. They may also start to feel policy represented if mainstream parties adopt stricter immigration policies due to their coalition with a PRR party. Finally, PRR parties may tone down their anti-elite rhetoric and thus stop fuelling nativist voters' discontent with the mainstream parties. Indeed, they may even start to talk positively about their coalition partners. The first mechanism suggests a short-term effect, whereas the latter two imply a long-term effect.

Crucially, we show that opponents of PRR parties (i.e., non-nativists) do not respond to inclusion strategies (or respond less drastically) by becoming less satisfied with democracy in the short term, arguably because they have built up a buffer of political support. Even though non-nativists may react strongly with their perceptions of the performance of the government, inclusion strategies will have an overall positive effect on SWD (in the short term). As a result, inclusion strategies are therefore usually followed by a net increase in satisfaction with the performance of the democratic political system.

This general trend is confirmed in a more stringent test on panel data from the Netherlands. Although Dutch non-nativists do lose SWD in the second year of the inclusion of Wilders' Party for Freedom (PVV), this is likely confounded by the start of the Euro crisis, which led to a strong decrease in SWD across the board. The year the inclusion started, non-nativists started to strongly dislike the government, but this did not negatively affect their satisfaction with the performance of democracy, whereas it increased strongly among nativists. This is in line with our argument that long periods of perceived positive performance contribute to a buffer of political support (among non-nativists). Thus, they put the blame on the current government rather than on the democratic political system per se.

Our findings highlight the dilemma faced by mainstream parties. Strategies of inclusion do indeed increase political satisfaction among nativists. At the same time, it somewhat decreases satisfaction with the way democracy works among non-nativists. The fact that the net effect seems positive because the nativists' reaction is stronger than non-nativists' reaction, however, provocatively points to the conclusion that general SWD will increase if established parties continue their inclusive strategies towards PRR parties, at least in the short term. This is also suggested by a recent study on the effects of the inclusion of the Norwegian Progress Party in government after the 2013 election (Haugsgjerd, 2019).

At the same time, the long-term consequences for political support and democratic legitimacy are harder to predict. There is of course a possibility that longer periods of inclusion of PRR parties might have a stronger eroding effect on SWD among the opponents of the PRR parties as a result of feelings of being 'outsiders' in terms of system responsiveness and a perceived erosion of liberal democracy. It might also be the case that the strong positive effect on satisfaction found among nativists is only temporary and that the boost in satisfaction will even out as high expectations are transformed into disappointment over lack of preferred policy changes and feelings of being betrayed by the party now being an integral part of the political establishment. In such a situation, 
the long-term net effect would be a general erosion of democratic legitimacy. Thus, the long-term implications of the processes investigated in this paper constitute an important avenue for future research. It should also be pointed out that the PRR parties do not constitute a homogeneous party family and that the PRR parties that hitherto have been included in any form of government cooperation have been more ideologically moderate.

A drawback with the current study is the limited amount of variation in our main independent variable (inclusiveness). Some points of departure for future research would thus be to aim for survey-embedded experiments. Such an approach would allow for elaborating on the mechanisms in relation to different strategies of inclusiveness and their impact on political support. An alternative approach could also be to opt for data with regional variation in party collaborations, although immigration issues mainly are decided at the national level. Another drawback is that our data do not allow us to separate between short- and long-term effects of inclusion. It will take more fine-grained panel data to do so. Nevertheless, our analysis shows that established parties' responses to PRR parties are important for understanding how the current wave of PRR party success around the Western world will affect citizens' satisfaction with the performance of democracy.

Supplementary material. To view supplementary material for this article, please visit https://doi.org/10.1017/ S1755773920000387.

Acknowledgements. We want to thank the editors and anonymous reviewers for their valuable comments throughout the process. We are also grateful to those who gave feedback at presentations at GESIS and the universities of Bergen, Oxford and Gothenburg. This research was made possible by grants from the Research Council of Norway (number 275308) and the Swedish Research Council (number 2018-01468). We thank Martin Instebø Jamne for his excellent research assistance.

\section{References}

Akkerman, T. and M. Rooduijn (2015), 'Pariahs or partners? Inclusion and exclusion of radical right parties and the effects on their policy positions', Political Studies 63(5): 1140-1157.

Anderson, C.J., A. Blais, S. Bowler, T. Donovan and O. Listhaug (2005), Losers' Consent: Elections and Democratic Legitimacy. Oxford: Oxford University Press.

Belanger, E. and K. Aarts (2006), 'Explaining the rise of the LPF: issues, discontent, and the 2002 Dutch election', Acta Politica 41(1): 4-20.

Bischof, D. (2017), 'New graphic schemes for Stata: plotplain and plottig', The Stata Journal 17(3): 748-759.

Blais, A., A. Morin-Chassé and S.P. Singh (2017), 'Election outcomes, legislative representation and satisfaction with democracy', Party Politics 23(2): 85-95.

Blinder, S., R. Ford and E. Ivarsflaten (2013), 'The better angels of our nature: how the antiprejudice norm affects policy and party preferences in Great Britain and Germany', American Journal of Political Science 57(4): 841-857.

Bustikova, L. and H. Kitschelt (2009), 'The radical right in post-communist Europe. Comparative perspectives on legacies and party competition', Communist and Post-Communist Studies 42(4): 459-483.

Canache, D., J. J. Mondak and M. A. Seligson (2001), 'Meaning and measurement in cross-national research on satisfaction with democracy', Public Opinion Quarterly 65: 506-528.

Citrin, J., M. Levy and M. Wright (2014), 'Multicultural policy and political support in European democracies', Comparative Political Studies 47: 1531-1557.

Dahlberg, S. and S. Holmberg (2014), 'Democracy and bureaucracy: how their quality matters for popular satisfaction', West European Politics 37(3): 515-537.

Dahlberg, S., J. Linde and S. Holmberg (2016), 'Democratic discontent in old and new democracies: assessing the importance of democratic input and governmental output', Political Studies 63(S1): 18-37.

Dalton, R. J. (2004), Democratic Challenges, Democratic Choices. Oxford: Oxford University Press.

Easton, D. (1965), A Framework for Political Analysis. Englewood Cliffs, NJ: Prentice-Hall.

Easton, D. (1975), 'A re-assessment of the concept of political support', British Journal of Political Science 5(4): 435-457.

Ezrow, L. and G. Xezonakis (2011), 'Citizen satisfaction with democracy and parties' policy offerings', Comparative Political Studies 44(9): 1152-1178.

Ferrín, M. (2016), 'An empirical assessment of satisfaction with democracy', in H. Kriesi \& M. Ferrín (eds.), How Europeans View and Evaluate Democracy, Oxford: Oxford University Press, pp. 283-306.

Foa, R.S. and Y. Mounk (2016), 'The danger of deconsolidation: the democratic disconnect', Journal of Democracy 27(3): 5-17.

Foa, R.S. and Y. Mounk (2017), 'The signs of deconsolidation', Journal of Democracy 28(1): 5-15. 
Giesselmann, M. and A.W. Schmidt-Catran (2019), 'Getting the within estimator of cross-level interactions in multilevel models with pooled cross-sections: why country dummies (sometimes) do not do the job', Sociological Methodology 49(1): 190-219.

Hamaker, E.L., R.M. Kuiper and R.P. Grasman (2015), 'A critique of the cross-lagged panel model', Psychological Methods 20(1): 102.

Harteveld, E., A. Kokkonen and S. Dahlberg (2017), 'Adapting to party lines: the effect of party affiliation on immigration attitudes', West European Politics 40(6): 1177-1197.

Haugsgjerd, A. (2019), 'Moderation or radicalisation? How executive power affects right-wing populists' satisfaction with democracy', Electoral Studies 57, 31-45.

Heinze, A.S. (2018), 'Strategies of mainstream parties towards their right-wing populist challengers: Denmark, Norway, Sweden and Finland in comparison', West European Politics 41(2): 287-309.

Hernández, E. (2016), 'Europeans' views of democracy: the core elements of democracy', in Kriesi, H. \& M. Ferrín (eds.), How Europeans View and Evaluate Democracy, Oxford: Oxford University Press, pp. 283-306.

Hooghe, M. and R. Dassonneville (2018), 'A spiral of distrust: a panel study on the relation between political distrust and protest voting in Belgium', Government and Opposition 53(1): 104-130.

Linde, J. and S. Dahlberg (2016), 'Democratic discontent in times of crisis?', in Peters, Y. \& M. Tatham, (eds.), Democratic Transformations in Europe: Challenges and Opportunities, London \& New York: Routledge, pp. 72-96.

Linde, J. and J. Ekman (2003), 'Satisfaction with democracy: a note on a frequently used indicator in comparative politics', European Journal of Political Research 42(3): 391-408.

Lindgren, K-O. (2006), Roads from Unemployment: Institutional Complementarities in Product and Labor Markets. Uppsala: Department of Political Science, Uppsala University.

Lubbers, M., M. Gijsberts and P. Scheepers (2002), 'Extreme right-wing voting in Western Europe', European Journal of Political Research 41, 345-378.

McLaren, L. (2012a), 'Immigration and trust in politics in Britain', British Journal of Political Science 42(1): $163-185$.

McLaren, L. (2012b), 'The cultural divide in Europe: migration, multiculturalism, and political trust', World Politics 64(2): 199-241.

McLaren, L. (2015), Immigration and Perceptions of National Political Systems in Europe. Oxford: Oxford University Press.

McLaren, L. (2016), 'Immigration, national identity and political trust in European democracies', Journal of Ethnic and Migration Studies 43(3): 379-399.

Meguid, B. (2005), 'Competition between unequals: the role of mainstream party strategy in Niche party success', American Political Science Review 99(3): 347-359.

Moffitt, B. (2018), 'The populism/anti-populism divide in Western Europe', Democratic Theory 5(2): 1-16.

Mudde, C. (2007), Populist Radical Right Parties in Europe. Cambridge: Cambridge University Press.

Norris, P. (ed.). (1999), Critical Citizens: Global Support for Democratic Governance. Oxford: Oxford University Press.

Pharr, S.J. and R. D. Putnam (eds.) (2000), Disaffected Democracies: What's Troubling the Trilateral Democracies? Princeton: Princeton University Press.

Rooduijn, M. (2018), 'What unites the voter bases of populist parties? Comparing the electorates of 15 populist parties', European Political Science Review 10(3): 351-368.

Rooduijn, M., W. van der Brug and S. L. de Lange (2016), 'Expressing or fuelling discontent? The relationship between populist voting and political discontent', Electoral Studies 43, 32-40.

Singh, S.P. (2014), 'Not all election winners are equal: satisfaction with democracy and the nature of the vote', European Journal of Political Research 53(2): 308-327.

Stecker, C. and M. Tausenpfund (2016), Multidimensional government-citizen congruence and satisfaction with democracy', European Journal of Political Research 55(3): 492-511.

Van Ham, Carolien and T. Jacques (2017), 'The myth of legitimacy decline: an empirical evaluation of trends in political support in established democracies', In C. van Ham, T. Jacques, A. Kees and A. Rudy (eds.), Myth and Reality of the Legitimacy Crisis, Oxford: Oxford University Press, pp. 17-34.

Van Spanje, J. and W. Van der Brug (2007), 'The party as Pariah: the exclusion of anti-immigration parties and its effect on their ideological positions', West European Politics 30(5): 1022-1040.

Van Spanje, J. and C.H. de Vreese (2014), 'The way democracy works: the impact of hate speech prosecution of a politician on citizens' satisfaction with democratic performance', International Journal of Public Opinion Research 26(4): 501-516.

Cite this article: Harteveld E, Kokkonen A, Linde J, and Dahlberg S (2021). A tough trade-off? The asymmetrical impact of populist radical right inclusion on satisfaction with democracy and government. European Political Science Review 13, 113-133. https://doi.org/10.1017/S1755773920000387 